\title{
クロツグミの生活史 繁殖期の生活
}

\author{
宮 沢 和 人* $^{*}$
}

I は じ め に

鳥類の生活史に関する研究は，欧米において古くから行なわれているが，我国で为最近多く の人々によって進められてきている。

ッグミ属 Turdus の鳥の繁殖生活については, Snow (1956, ’58) がクロッグミの近縁種で ある Blackbird Turdus merula について, また Cavies \& Snow (1965) が Song Thrush Turdus philomelos のナワバリおよび食物について報じている。我国では羽田・渡辺 (1969) のアカハラ Turdus chrysolaus についての研究があるが, クロッグミ Turdus cardis cardis の繁殖生活については黒田（1966）などの断片的な報告しかなされて抢らず，その詳細につい ては未だ明らかでない。筆者は1968年抢よび1969年の 2 年間にわたってクロッグミの繁殖期に おける生活史調查を行なってきたのでここに報告する。

本論に入るに先立ち, 御校閲御教授頂いた山階鳥類研究所黑田長久博士に対して厚く御礼申 し上げる次第である。

また，日頃御懇切な御教授を頂いている信州大学農学部森本尚武助教授掞よび文献をはに゙め として種々御懇切な御教示を頂いてきた信州大学教育学部羽田健三教授ならびに山㳸鳥類研究 所浦本昌紀博士に対して深謝の意を表する次第である。

\section{III調查地および調查方法}

調査はすべて長野県伊那市郊外の信州大学農学部構内（標高 $780 \mathrm{~m}$ ）に打いて行なった。 本調査地は大部分がアカマッ，ヒノキを主体とする針葉樹に覆われ，毎年渡来するクロッグ ミの数もきわめて多い。調查方法は 1 巣についての終日観察を主とし, その他随時断片観察を 行なった。終日観察に際しては巣位置から 4 ～ 5 mの地点にブラインドを設置し，その中から 9 倍の双眼鏡によって行なった。ナワバリの分布抢よび繁殖状況に閔する調査は約 13ha の区 域を中心に行ない, 特にナワバリの分布に関しては, 道路あるいは林縁部からの song post を中心としたマッピングにより，また各個体の移動が認められた範囲内までの行動跡を地図上 に記入することによって行なった。本論では主として1969年 5 月初旬に繁殖を開始したひと番 い(A番以)に打ける Ist brood を扱っている。

\section{III 結果および考察}

1. 渡来

本種は我国に夏鳥として渡来する。本調查地での初認は1968年は 4 月13日，1969年は 4 月 15

*387. 長野県更埴市大字粟佐 1,322 
日であった。従って両年にわずかな差はあるが，4月の中旬に渡来が開始されることがわかる。 雌雄の渡来日ではオオヨシキリ Acrocephalus arundinaceus orientalis (羽田・寺西 1968) や アカモズ Lanius cristatus superciliosus（羽田・高橋 1968）等に执いてりみられるように， 雄の方がわずかに早く渡来する場合が多く, 雌が渡来すると雄の雌に対する地上での追尾行動 がみられ，雄個体間の激しい争いるしばしばみられる。

2. 繁殖の開始および繁殖回数

クロッグミの繁殖は4月下旬から始まる。

産卵の開始は1968年抢よび1969年の雨年とり最り早い巣で5月 5 日であった。これらはそれ ぞれ 5 月 2 日，5月 1 日に巣を発見して抢り，すでに 4 月下旬から巣造りが開始されたるのと 考えられる。第 1 図に示すように多くの番、は 5 月上旬から中付にかけて産卵を開始している がG番いのような初卵日の遅れはSnow（1958）が述べているように，特に若烏に执いてみら れる番いの形成もしくはナワバリ占拠の痋れのためであろう。

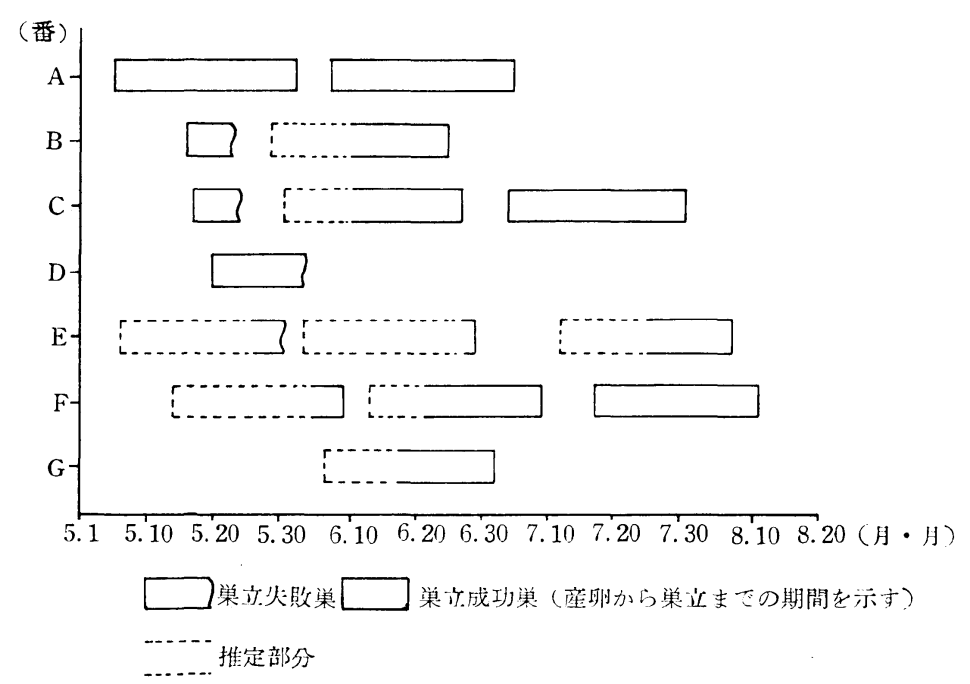

第1四各番々の nest-cycle

また，クロッグミではシーズンに 1 回以上の繁殖をするりのが多く, 番い当りの平均繁殖回 数は巣立ち失敗巣も含めると 2.1 回, 成功巣の平均は 1.6 回であった。一方近縁種の blackbird でり普通 1 シーズンに $2 \sim 3$ 回の繁殖を行ない, 成鳥では平均 3.1 回, 若鳥では平均 2.3 回の 産卵を行なっている(Snow 1958)。

このようにシーズンに 1 回以上の繁殖をするりのにはヒバリ Alauda arvensis japonica （羽田・小淵 1967）やシジュウカラ Parus major（浦本 1966）のようなるのにりみられる が, シジュウカラに㧍㳊第 2 回目の繁殖は雌の年齢, 個体群密度, 平均初卵日等種々の要因 によってその割合に差がある（浦本 1966）という。

巣立ち日あるいは卵雛の消失日から次の産卵に入るまでに要する日数は2〜12日（推定为含 む）で平均 5.6 日であった。また， blackbird で山多くは 4 〜 10日であるからクロッグミとほ ぼ等しいといえるだろう。従って我国のクロッグミと欧州に分布する blackbird では上述の 
点に関してきわめて生態的 な類似性に富んでいること がうかがえる。

3. 繁殖経過の区分

繁殖諸行動の期別变化を 第 2 四に示した。

クロツグミの繁殖経過は

1 回の繁殖を例にとってみ ると, 入巣時間, 入巣回数 雛への給餌回数等から次の 5 期に区分される。

（1）巣造り期 巣材運搬開始加第 1 卵が産下されるまでの

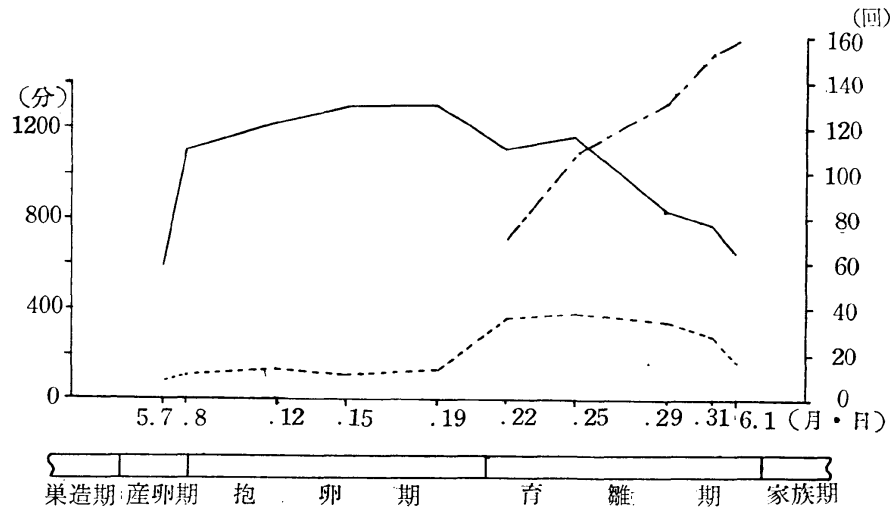

第 2 図 繁殖諸行動の期別変化

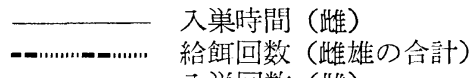

入㧛回数（此）

期間で，巣造り開始から初卵日まで 8 日を要したりのを1970年度に 1 例観察した。

\section{(2) 産卵期}

第 1 卵産卵から終卵が産下されるまでの期間で $2 〜 4$ 日間。産卵のための入巣がみられる ほか産卵の前後においてわずかの入巣が行なわれ，夜間抱卵は終卵 1 日前の夕方から行な われる。

(3) 抱卵期

最終卵産卵日から孵化までの期間で12〜13日間。夜間，日中の抱卵が長時間にわたって行 なわれる。

\section{(4) 育離期}

卵孚化日から巣立ち日までの期間で11〜13日間。雛への給慨および抱雛が行なわれる。

\section{(5) 家族期}

巣立ち日から家族崩壊までの期間で約 20 日間。

以上の結果から, 巣造り開始から家族崩壞までは, 少なくとも 1 力月半を要している。

4. 巣造り

\section{（1）巣造り場所および巣の構造}

1968年および1969年に観察された巣造り 場所は第 1 表に示すように36例中 35 例が針 葉樹に造られていた。これらはほとんどが 枝の付根に造られ，いずれも道路付近また は林縁部に集中している。

営巣高別にみた巣数を第 3 図に示したが 最低 $1.3 \mathrm{~m}$ から最高 $7.9 \mathrm{~m}$ までに造られて 打り，1〜3mの此較的低小場所に造られ ていたものが最も多く, 全体の半分以上を 占めていた。

第 1 表 営巣場所および巣の構造

\begin{tabular}{|c|c|c|c|}
\hline 営巣樹種 & 例 数 & \multirow{2}{*}{$\begin{array}{l}\text { 営㫦樹高 } \\
\text { 営 栄 高 }\end{array}$} & $2.2 \sim 16.0 \mathrm{~m}$ \\
\hline ア カ & 15 & & \\
\hline ス & 9 & & 形 \\
\hline 七 & 5 & 径 & $7.0 \sim 10.5 \mathrm{~cm}$ \\
\hline カ ラマ & 3 & 径 & $12.0 \sim 17.0 \mathrm{~cm}$ \\
\hline サ ワ & 2 & 深 & $3.0 \sim 6.0 \mathrm{~cm}$ \\
\hline ネズミサシ & 1 & 㕌さ & $7.0 \sim 11.0 \mathrm{~cm}$ \\
\hline モウソウチク & 1 & & \\
\hline
\end{tabular}




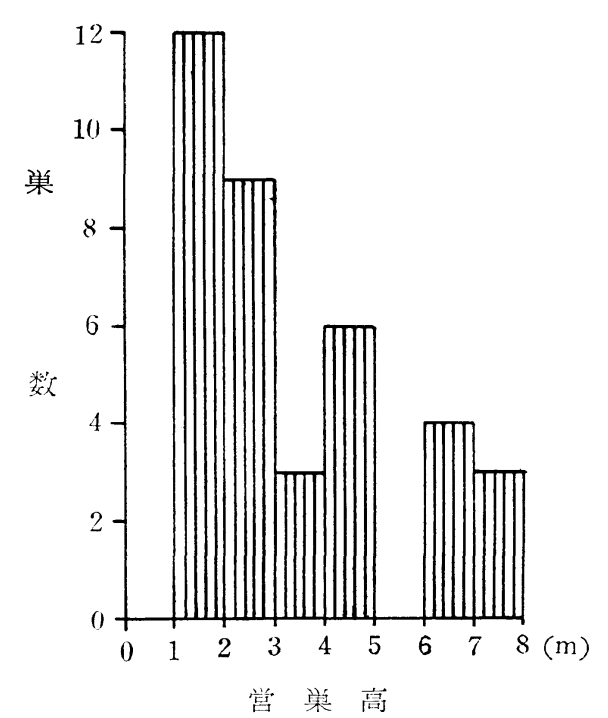

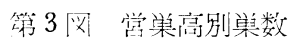

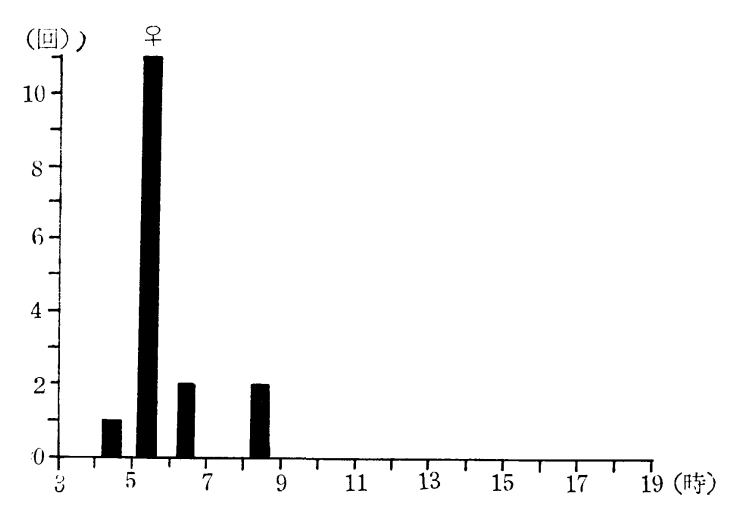

第 4 図 栄材運搬回数の日周変化 机た。

これはクロッグミが主として, 地上採食型の鳥 であることから生活空間がより地上に面した部分 に広がり，このため営巣場所も比較的低い場所を 選んでいるものと考えられる。

巣材は外装がコケ, 落葉落枝の腐蝕土, ビニー ル類, 樹根, 草根, 枯草などが用いられ，内装に はアカマッの枯葉, 草本類の細根, 獣毛などが使 われていた。

\section{(2) 巣造り行動}

第 4 図抢よび第 5 図にA番いの 2 nd broodに おける巣造り行動について示した。

第 4 図はすでに内装造りに取りかかっていた 6 月 5 日の巣材運搬回数の日周変化であるが, 巣材 運搬は午前中に行なわれ，雌のみによって行なわ

また，第5図から明らかなように巣材採取はす ベてナワバリ内の地上から行なわれ， 特に巣に近い同一場所からくり返し行 なわれる傾向があった。雌は口いっば いに巣材をくわえると直接巣に向い, 産座に巣材を落してから直ちに入巣し 30 秒（最小）から 7 分間（最大）腹之 胸で強く押しつける行動をくり返した

5. 産卵行動

産卵は巣の完成から 1 〜数日後に 1 日 1 卵づつ連続して行なわれた。

第 2 表に産卵時刻と産卵に要する入 巣時間を示したが，産卵はかなり一致 した24時間周期で行なわれ，産卵時刻は $8: 00 〜 12: 00$ 間でいずれも午前中であった。また 産卵のための入巣時間はかなり長く, 平均 107 分であったが, この間に数分尾を巣中に深く下 げるような動作をし，この時に産卵されるものと思われる。産卵時刻については，同属の blackbird でも Snow (1958) が8：00〜12：00の間という報告をして抢りクロッグミの場合と一 致している。1 復の卵数は $3 〜 5$ 卵で 3 卵のものが $20.0 \% ， 4$ 卵が $70.0 \% ， 5$ 卵が $10.0 \%$ ， 4 卵が大部分を占め平均卵数は 3.9 卵であった。

6. 抱卵

抱卵は雌のみによって行なわれた。抱卵行動は第 1 卵産卵日からみられたが，長時間の安定 した抱卵は最終卵産卵日から行なわれた。

第 6 図に抱卵時間の日周変化を示すように, 終卵 1 日前の産卵第 3 日目の夕方から夜間抱卵 が行なわれ，終卵日には完全抱卵に入った。産卵第 2 日目 ( $\mathrm{A}_{2}$ 巣) では 249 分の入巣が行な 


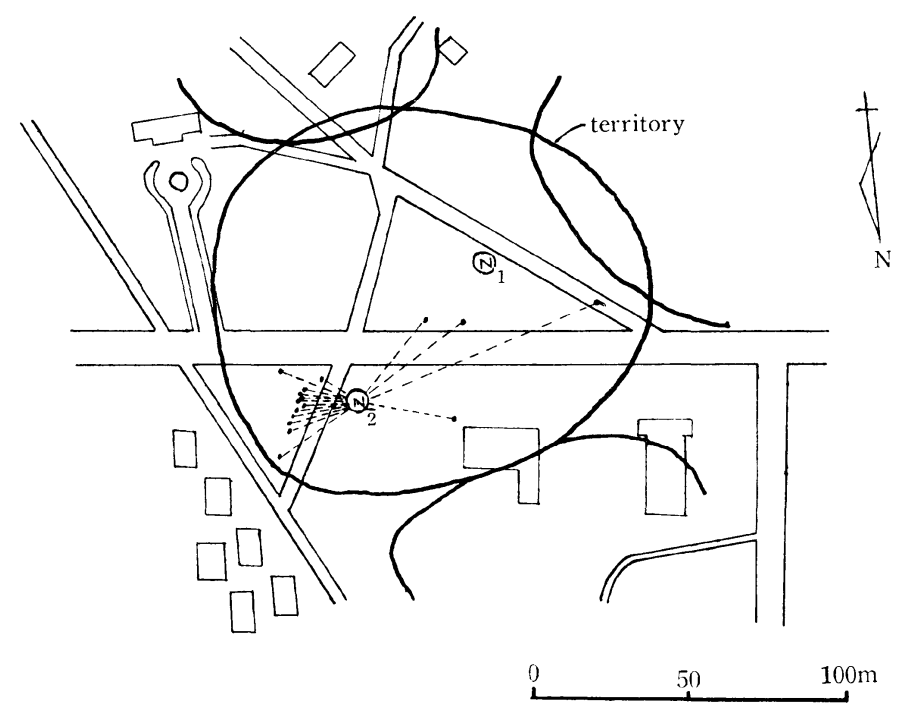

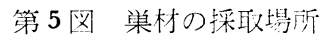

第 2 表 産卵時刻および所媭時間

\begin{tabular}{|c|c|c|c|c|c|}
\hline 栄 & 産 & 卵 日 & 㢁 即 & 洔刻 & 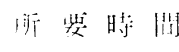 \\
\hline $\mathrm{A}_{1}$ & $\begin{array}{l}5.7 \\
5.8\end{array}$ & $\begin{array}{l}\text { 第 } 3 \text { 卵日 } \\
4 \text { (終畉) }\end{array}$ & $\begin{array}{l}8: 30 \\
9: 00\end{array}$ & $\begin{array}{l}\sim \quad 10: 08 \\
\sim \quad 10: 15\end{array}$ & $\begin{array}{l}98 \text { (分) } \\
75\end{array}$ \\
\hline $\mathrm{A}_{2}$ & $\begin{array}{l}6.8 \\
6.9\end{array}$ & $\begin{array}{l}2 \\
3\end{array}$ & $\begin{array}{l}9: 25 \\
8: 50\end{array}$ & $\begin{array}{l}\sim \quad 11: 40 \\
\sim \quad 10: 50\end{array}$ & $\begin{array}{l}135 \\
120\end{array}$ \\
\hline
\end{tabular}

われただけで，24時間に対する割合は17.2\%にすぎず，また $A_{1}$ 巣の産卵第 3 日目には夜間抱 卵が行なわれ，1日の41.5\%を占めるが終卵が産下された日からは 1 日平均1224.9分の抱卵が 行なわれ，入巣時間は 1 日の $85.1 \%$ と達している。

抱卵第 1 日目には，朝と夕方に抱卵時間の減少がみられるが抱卵期の進行に伴い抱卵時間に かなりの安定性がみられる。すすねわち，第 3 表に示す平均入巣時間から抱卵気分の増大は 1 回 の抱卵持続時間の上にも表われ，抱卵第 8 日目と第 12 日目にはいずれも50分以上という抱卵初 期における，それよりも長い持続時間を示している。抱卵期にお打る抱卵持続時間は 14〜101 分で平均 49.8 分，出巣時間は $4 \sim 89$ 分で平均 15.4 分であった。

また，1968年の 1 巣に打ける合計 30 時間の観察によると，平均抱卵持続時間が37.0分，平均 出巣時間は 15.2 分であった。

抱卵期に抢ける 1 日の入巣回数は11〜13回で変動は少なく，ヒバリ（羽田・小淵 1967）や オオヨシキリ（羽田・寺西 1968）のような小型種に比べると出巣，入巣のリズムがきわめて 緩慢で，安定したリズムによって抱卵を続けていることがわかる。

7. 育雛

(1) 卯孚 化 

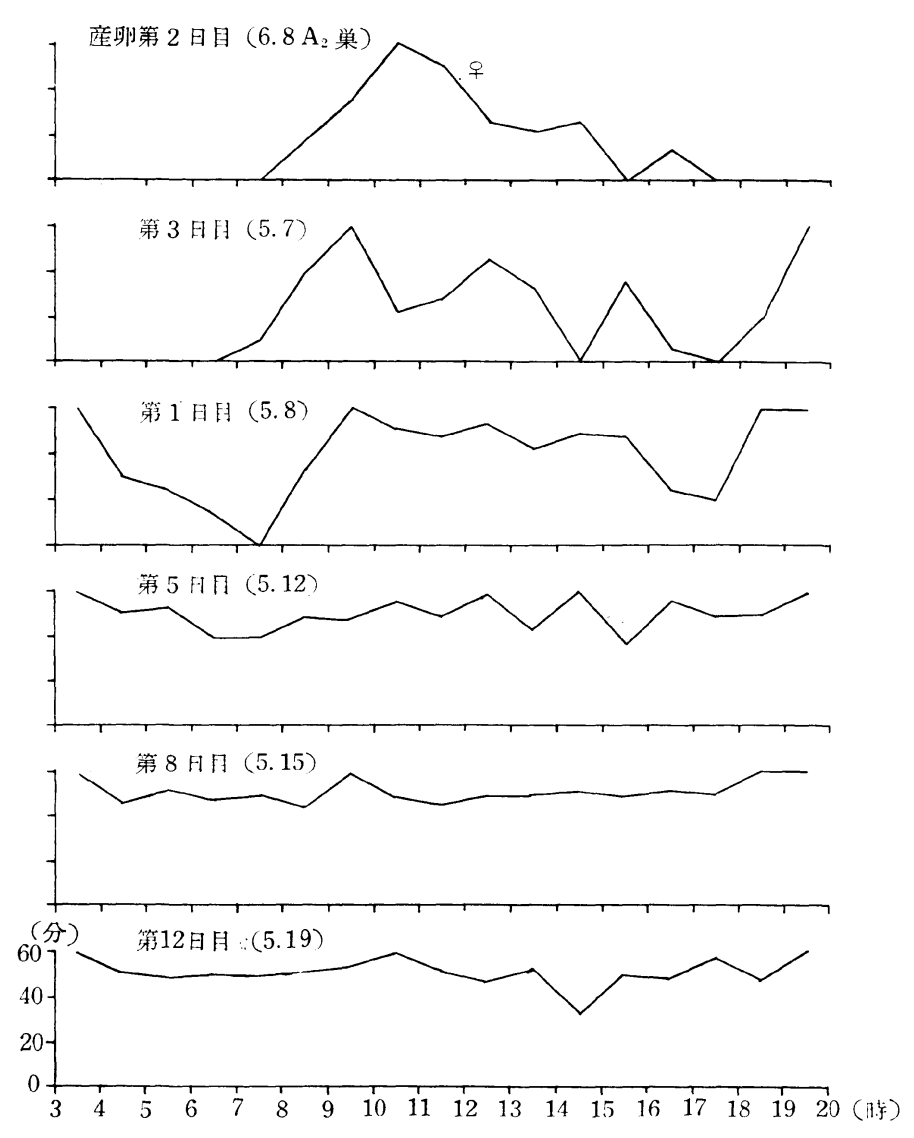

第 6 四 抱卵時間の口周変化

第 3 表 各期別の平均入巣洔間

\begin{tabular}{|c|c|c|c|c|}
\hline & 日 & 入紧回数 & 総入栄特問 & 平均入单時間 \\
\hline \multirow{2}{*}{$\begin{array}{l}\text { 锂 } \\
\text { 期 }\end{array}$} & 6.8 & 7 (回) & 249.0 (分) & 35.6 (分) \\
\hline & 5.7 & 8 & 278.0 & 34.8 \\
\hline \multirow{4}{*}{$\begin{array}{l}\text { 抱 } \\
\text { 贸 } \\
\text { 期 }\end{array}$} & 5.8 & 11 & 457.0 & 41.5 \\
\hline & 5.12 & 13 & 621.0 & 47.8 \\
\hline & 5.15 & 11 & 637.0 & 57.9 \\
\hline & 5.19 & 13 & 677.5 & 52.1 \\
\hline \multirow[b]{2}{*}{ 育 } & 5.22 & 36 & 535.0 & 14.9 \\
\hline & 5.25 & 38 & 581.0 & 15.3 \\
\hline \multirow{3}{*}{$\begin{array}{l}\text { 雛 } \\
\text { 期 }\end{array}$} & 5.29 & 35 & 275.0 & 7.9 \\
\hline & 5.31 & 28 & 217.5 & 7.8 \\
\hline & 6.1 & 16 & 107.5 & 6.7 \\
\hline
\end{tabular}


完全抱卵に入った日から13〜14日目に卯孚化する。これはアカハラ（羽田・渡辺 1969）の抱 卵日数14日，また blackbird (Snow 1958) の13.7〜12.7日とほぼ一致する。

卵化順序について，1968年および1969年のそれぞれ 1 巣について産卵順につけたマークから 検討したが，1968年の 1 巣では第 3 卵と第 4 卵が13日目の午前中に, 第 5 卵は 1 日遅れて 14 日 目に綧化し，第 1 卵が無精卵，第 2 卵が死卵として残された。1969年の 4 卵の $\mathrm{A}_{1}$ 巣では，第 1 卵と第 2 卵に13日目の午前中からひび割れが生じていたが, 当日の18時の観察では全く変化 がみられなかった。結局, 第 1 卵, 第 2 卵は14日目11時の観察以前に卵孚化して抢り, 第 3 卵と 第 4 卵にはこの時ひび割れがみられたが，第 3 卵は11:00〜 12:30の間に，第 4 卵は12:30〜 14：00の間に卵孚化した。これは blackbirdに打いても確認されて打り，抱卵行動が第 1 卵と 共に始まるため，早く産卵された卵ほど発育がわずかに早いことを示している。

孵化しなかった卵は, 㮲隹の巣立ち後までそのまま巣中に放置された。

\section{(2) 抱離}

抱微抱抑と同様に雌のみによって行なわれた。第 7 図に抱㥮時間の日周変化を示したが， 日中の抱雛は雛の成長にともなって次第に減少していく。夜間抱雛は最後まで行なわれたが日 中の抱瀿時間は，その日の天候にも影響されると思われる。例えば，育雛第 5 日目（5月25 日）には終日雨降りであったため, 育㮲第 2 日目（5月22日）の入巣時間の合計 1,105 分に対 して 1,160 分であった。また平均入巣時間方育駣第 2 日目の 14.9 分に比べて 15.3 分とわずかに 長くなっている。このように抱佯行動は外的条件によっても影響を受汁る。

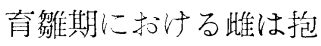

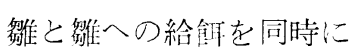
行なわなけ机ばならない ため, 1 日の入巣回数は 抱卵期に比べてかなり多 くなり, 平均入巣時間は 短くなる(第 3 表)。

また抱篗中の雌は雄が 給餌に来た際に離巣し， 後に飭をくわえて訪巣し 給䬦直後に再び抱㱀を続 けるという型をとるが， 巣中に立ち上がるかある いは巣のふちにとまるの みで, 雄の給飭が済むと 再び抱敬しつづける場合 が育䇖初期のみにみられ た。従って育薙初期には まだかなりの抱卵気分が 継続していることが予想 される。
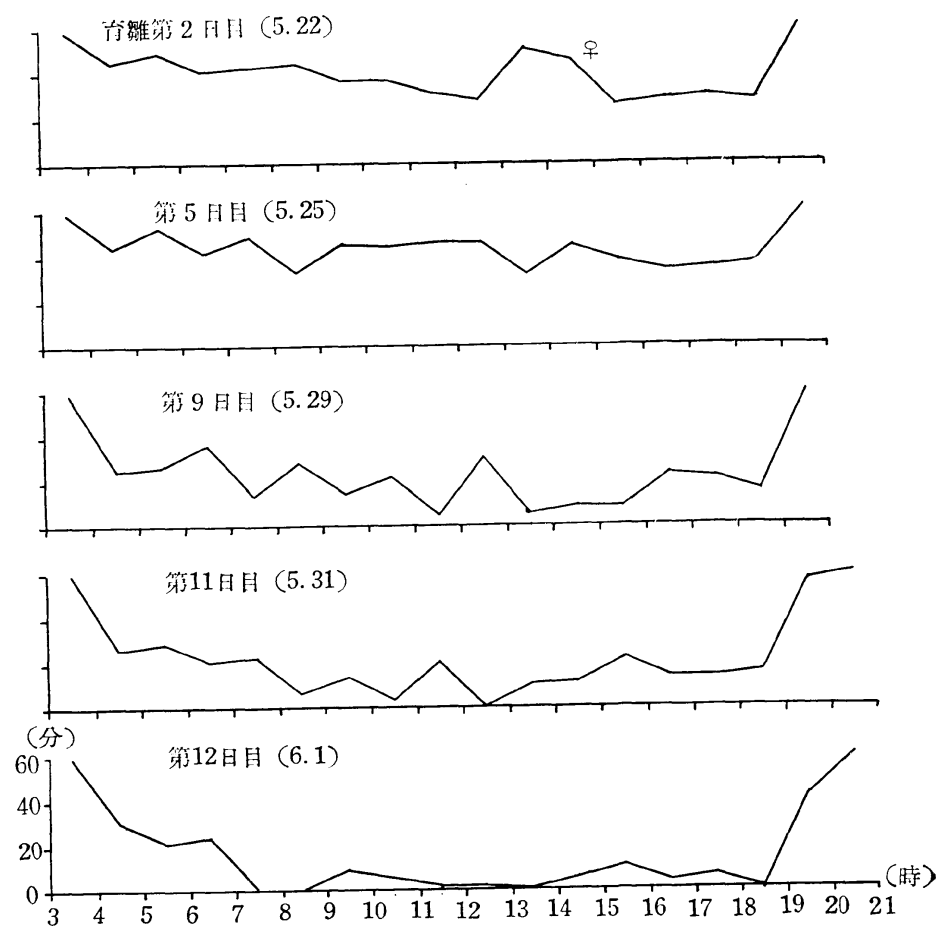

第 7 図 抱雛時閒の日周変化 
第 4 表 給餌回数

\begin{tabular}{|c|c|c|c|c|c|c|}
\hline \multirow{2}{*}{\multicolumn{2}{|c|}{ 観 察 }} & \multirow{2}{*}{ 冬 日 } & \multirow{2}{*}{ 㱀数 } & \multicolumn{3}{|c|}{ 給 餌 回 数 } \\
\hline & & & & 雄 & 雌 & 合計 \\
\hline 5.22 & （育触会 & 第 2 口目） & 4 & 39 & 31 & 70 \\
\hline 5.25 & ( $\hat{\mathrm{s}}$ & 第 5 日目) & 3 & 74 & 34 & 108 \\
\hline 5.29 & ( & 第 9 日目) & 3 & 84 & 47 & 131 \\
\hline 5.31 & ( & 第11日目) & 3 & 95 & 58 & 153 \\
\hline 6.1 & ( & 第12日目) & 3 & 84 & 74 & 158 \\
\hline
\end{tabular}

\section{（3） 給餌}

給嘅行動は卵孚化日から始まり，雌雄によっ て行なわれた。

給餌形態について，その大部分は慨を運ん できた親が直接雛に慨を分割して与えた。

1 日の給餌回数は第 4 表に示すように雛の 成長にともなって次第に増加し，巣立ち前日 の育雛第 12 日目（6月 1 日）には育雛第 2 日 目（5月 22 日）の総回数回に比べて 2 倍以上 の158 回に達している。こ れを雌雄別にみると，雌は 觹の日齢が進むにつれて次 第に增加していくが，雄は 育雛第11日目の95回に対し て翌日の第12日目には84回 に減少している。こ礼は此 の急激な給慨の増加により 雛の慨の要求量が緩和され たことによる为のと考えら れる。第 8 図に示した給餌 回数の日周変化をみると， 育籊期を通して特に一定し た変化はみられないが，育 雛初期には特に朝夕に多く 後期にはむしろ $8 \sim 9$ 時打 よび12〜13時頃に多くなっ ている。

また第 9 図に示した給餌 回数の総計に抢ける日周変 化では，雌雄ともにほぼ同 型の変化を示し，8時掞よ

び18時頃に特に多く, 次いで 4 時および13〜 14時頃にピークを示している。従って $3 \sim 4$ 時間 おきの周期的なピークがみられるが，これは雛の空腹状態によって起こる求餌行動の二強さ= に比例するむのであろう。

なお，雛は給餌直後に排粪するが，親はそれをほとんどのみ込みによって処理し，巣外に運 び去ったのは育雛第 9 日目と第12日目にそれぞれ一度観察されただけであった。

\section{(6) 触の成長}

睬化当時の㑳倠は背と頭部および屃の部分に $10 \mathrm{~mm}$ 程度の薄黄色あるいは灰黒色のわずかの羽 
毛が生えているが，目は忘 た開いていない。しかし， 孵化後4〜5日目になると 目が開き，翼の羽根の延び 当顕著になってくる。

第 5 表に巣立ちまで成功 した倣 7 羽（3 巣分）门日 齢ごとの体重掞よびその平 均を示した。卵化当時の䑝

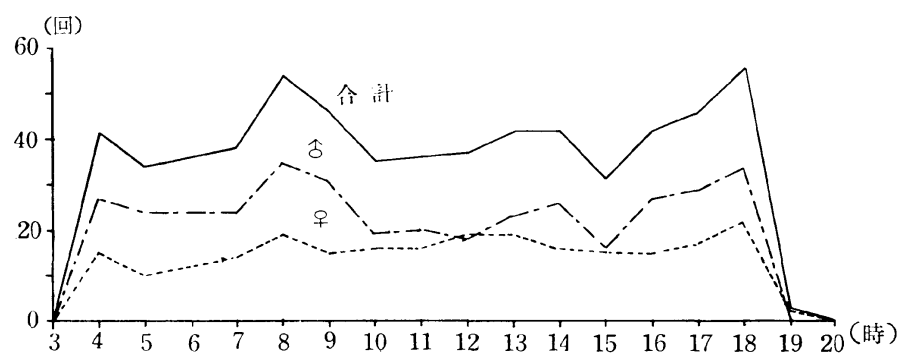

第 9 网 給䬧回数の総計に拉け万日周変化

第 5 表 雛の体重

(単位：グラム)

\begin{tabular}{|c|c|c|c|c|c|c|c|c|c|c|c|c|c|c|}
\hline 单 & 日齢 & 1 & 2 & 3 & 4 & 5 & 6 & 7 & 8 & 9 & 10 & 11 & 12 & 13 \\
\hline \multirow{2}{*}{\multicolumn{2}{|c|}{$\mathrm{A}_{2}$}} & 6.5 & 10.7 & 15.2 & 19.7 & 26.5 & 34.8 & 42.0 & 43.0 & 44.7 & 39.6 & - & 栄 & \\
\hline & & 5.6 & 8.7 & 13.5 & 18.7 & 27.3 & 32.0 & 35.1 & 40.3 & 42.2 & 43.3 & -- & 5 & \\
\hline \multirow{2}{*}{\multicolumn{2}{|c|}{$\mathrm{B}_{2}$}} & 5.0 & 7.3 & 11.7 & 19.2 & 20.9 & 25.2 & 30.8 & 36.0 & 41.2 & 44.9 & 46.0 & 46.2 & 媇 \\
\hline & & 5.3 & 8.2 & 13.2 & 15.7 & 24.3 & 30.5 & 34.2 & 37.3 & 41.5 & 43.7 & 45.5 & 46.7 & 立 \\
\hline \multirow{3}{*}{\multicolumn{2}{|c|}{$\mathrm{C}_{2}$}} & 4.4 & 7.6 & 12.9 & 18.6 & 23.8 & 30.3 & 38.0 & 42.0 & 43.4 & 44.8 & 46.5 & \multirow{3}{*}{$\begin{array}{l}\text { 采 } \\
\frac{11 .}{5} \\
\frac{5}{5}\end{array}$} & \\
\hline & & 5.4 & 8.6 & 13.0 & 18.6 & 24.9 & 32.2 & 39.2 & 44.2 & 45.9 & 46.0 & 45.1 & & \\
\hline & & 4.8 & 7.5 & 13.1 & 19.8 & 24.8 & 31.7 & 35.6 & 39.7 & 43.5 & 42.1 & 44.2 & & \\
\hline 平 & 均 & 5.29 & 8. 37 & 13. 23 & 18.61 & 24.64 & 30.96 & 36.41 & 40.36 & 43.2 & 43.49 & 45. 46 & 46.45 & \\
\hline
\end{tabular}

の体重は平均 $5.29 \mathrm{~g}$ で，巣立ち前日には平均 $45.54 \mathrm{~g}$ に達する。

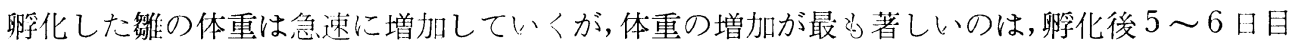
頃で 1 日に $6 \mathrm{~g}$ 以上增加する。孵化後 6 日目からは次第に 1 日の増加量が減り，10〜11日目 に前日の体重よりわずかに減少する例が3 例みられたが，一般に巣立ち前日まで増え続けるも のが多い。巣立ち近くの雛の減少について，蠟山(1961)は生まれたばかりの雛はほとんど運動 せず，また呼吸回数的少なく，体温調節機能りない。このため摂食量の大部分は成長に使われ るが，運動量が增し体温調節機能が完成すると，摄食量は $100 \%$ 呼吸に使われるようになり， 呼吸量を上まわってしまうためであると述べている。従って第 5 表から㱀の体温調節機能の完 成は, 育雛第 9 日目前後であることが推察されるが，第 7 図に示した抱雛時間の日周変化から り親の抱篗時間の減少によってそれが明らかである。

$\mathrm{B}_{2}$ 巣に扒いて孵化後第 2 日目と第 5 日目に雛の死亡が確認さ机たが，翌日には巣内に残さ れていないことから，親によって運び出されたものと思われる。死亡雛の親による運び出しは オオヨシキリ（羽田・寺西 1968）やblackbird（Snow 1958）等においても観察されている。 8. 巣立ち打よび家族生活

巣立ちは卵化後11〜13日目に行なわれ，1日のうちに全雛が一斉に巣立った。巣立ちが近づ くと巣上での羽ばたきが急に活発になり，1969年の $\mathrm{A}_{1}$ 巣では雞 1 羽が巣立ち前日の育雛第 12 日目に巣上での羽ばたきと同時に巣を支えているアカマツの枝にとび移ったが，親が給慨に来 た際すぐ巣に戻っている。このような行動はアカモズ(羽田・高橋 1968)でもみられるが，全 
雛が巣立のた後再び巣に戻るということはない。

1968年の1紧にお゙いて巣立ちに関する直接の観察がなされたが，1 羽が 9 時02分に巣上での 羽ばたきと同時に前の枝にとび移り，続いて地上にとび下りた。これょり 103 分間を扒いて10 時45分に残りの 2 羽が同時に直接地上にとび下りることによって巣立っている。

巣立ち後の家族行動は，1968年の!巣抢よび1969年の 6 巣の雊にカラーリングでマーキング して観察した。巣立ち当時の鹤はまだほとんど飛翔能力はなく，一力所に停っている時間が長 いが，巣立ち後 3 日目頃になると飛翔能力引増し行動り広範囲に打よぶ。この頃の雛は一力所 にまとまり，特に地上で親から給慨される場合が多くなる。

雌が次の繁殖に入った場合, 雌の給餌は約 1 週間続くのみで後は雄のみによって行なわれた。 1968年のひと番いに抢ける例では，2回目の繁殖は確認できなかったが，雌の給慨は雛の巣立 ち後7日目まで行なわれ，その後は雄のみによって行なわれた。また巣立ち後21日目には家族 群の崩䁲がみられ，雛はそれぞれ独自で採食していた。1969年のA番いにおける 1 st brood では，㹊の給䬦が巣立ち後 6 日目までみられたが，以後の給慨には雄のみがたずさわってい る。この 6 日目はすでに 2 nd brood の産卵第1 日目に当り，巣立ち後16日目には家族群の崩 壊がみられた。また $\mathrm{E}$ 番いに拈ける 2 nd brood の観察では，18日目までの給謒を確認し，F 番いに抢ける 1 st brood では 2 nd brood の産卵第 2 日目（推定）に当る巣立ち後 6 日目ま での雌の給䬣を確認している。
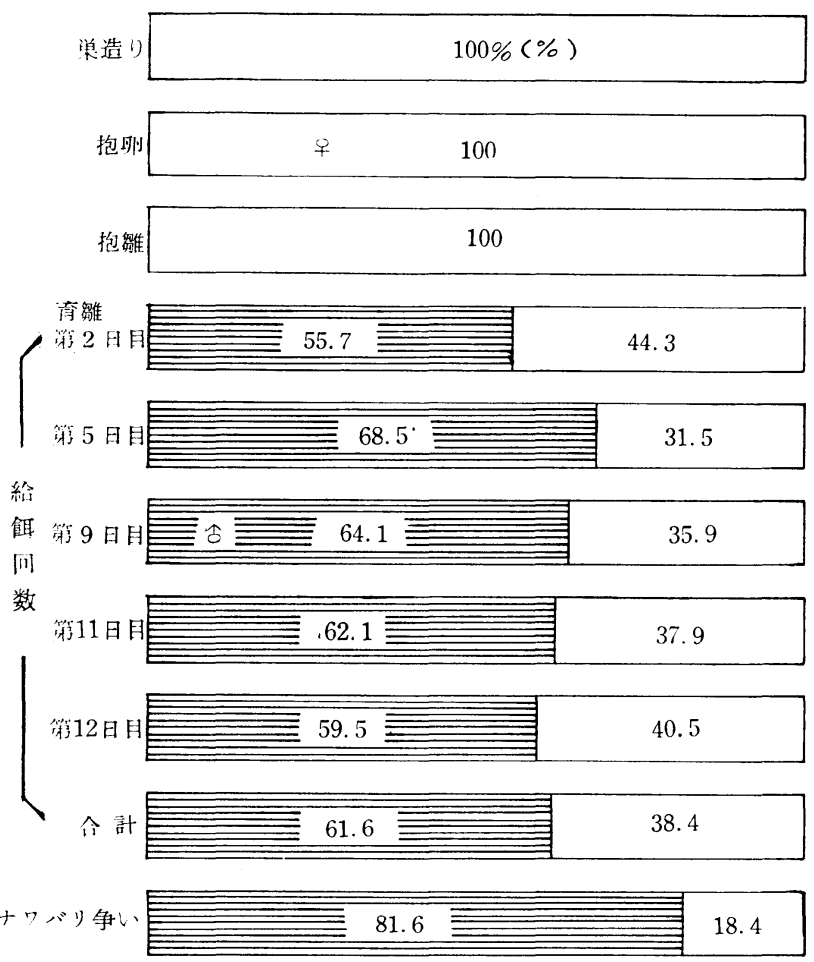

第10図 繁殖諸行動の雌雄別割合
以上の結果から家族期の長さ は20日前後と推察されるが，雌 が次の繁殖に入った場合以後の 㬬の世話を雄のみに任せ，1 シ ーズンに $2 \sim 3$ 回の繁殖を可能 ならしめるきわめて合理的な仕 組がここに見出せる。家族期間 については Snow (1958) が blackbirdについて報じている が，クロッグミときわめて類似 して打り約20日間で, 雌が次の 繁殖に入った場合は, クロッグ ミと同様に雌から雛への給飭期 間は約 1 週間であるという。

9. 繁殖諸行動の雌雄による分 担

第10図に繁殖諸行動の雌雄別 割合を示したが，雌雄間にかな りはっきりした機能分担がみら れた。

巣造り，抱卵，抱雛は全て倠 
によって行なわれたが，2 nd brood の育雛第10日目（7月 2 日）に激しい降雨中一度だけ， 雄が雛の上に数秒すわり込むのが観察された。これは雄の抱雛行動といえるかどうか疑問であ るが，降雨による外的刺激によって，偶発的になされた行動と思われる。一方アカハラ（羽田

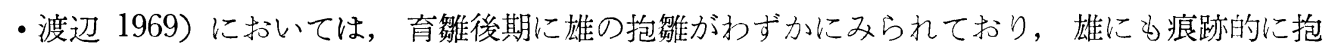
雛本能が残っているものと考えられる。

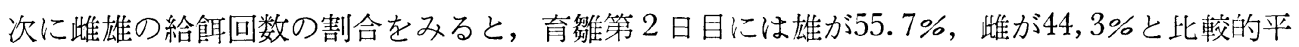
均しているが, 第 5 日目には雄 $68.5 \%$, 雌 $31,5 \%$ と差がでてくる。しかし, 抱雛行動の隇少

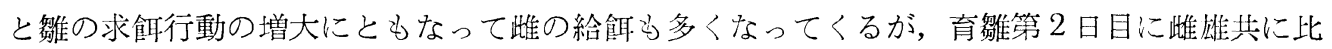
較的近い比率を示しているのは, まだ雛の䬣の要求量も少ないため雄の給䬣回数り少なく, 抱 雛中の雌はほとんどが雄が給慨に来た時だけに離巣し，その後慨を持って訪巣するという型を とるためである。すなわち, 育雛初期に抢ける雌の離巣要因は, 特に雄の給邻によるっのが多 く, 従って抱刎時間と給䬣回数の時刻による増隇は逆の関係を示している（第 7 ・ 8 図）。給 餌回数全体からみた雌雄の割合は, 雄 $61.6 \% \%$, 雌38.4\%で雄の方が雌より多く, また1968年 の 1 巣に抢ける観察でも雄 $68.7 \%$, 雌 $31.3 \%$ と雄が主体をなしている。また，雄の給仰が最斗 多かった育雊第11日目に, 雄は平均 9 分に 1 回の割合で雛に給邻しており, いかに多くの時間 を採慨に費しているかがわかる。

ナワバリ防衛行動の争いについても同様に雄が圧倒的に多く，雄が81.6\%，雌が18.4\%たあ

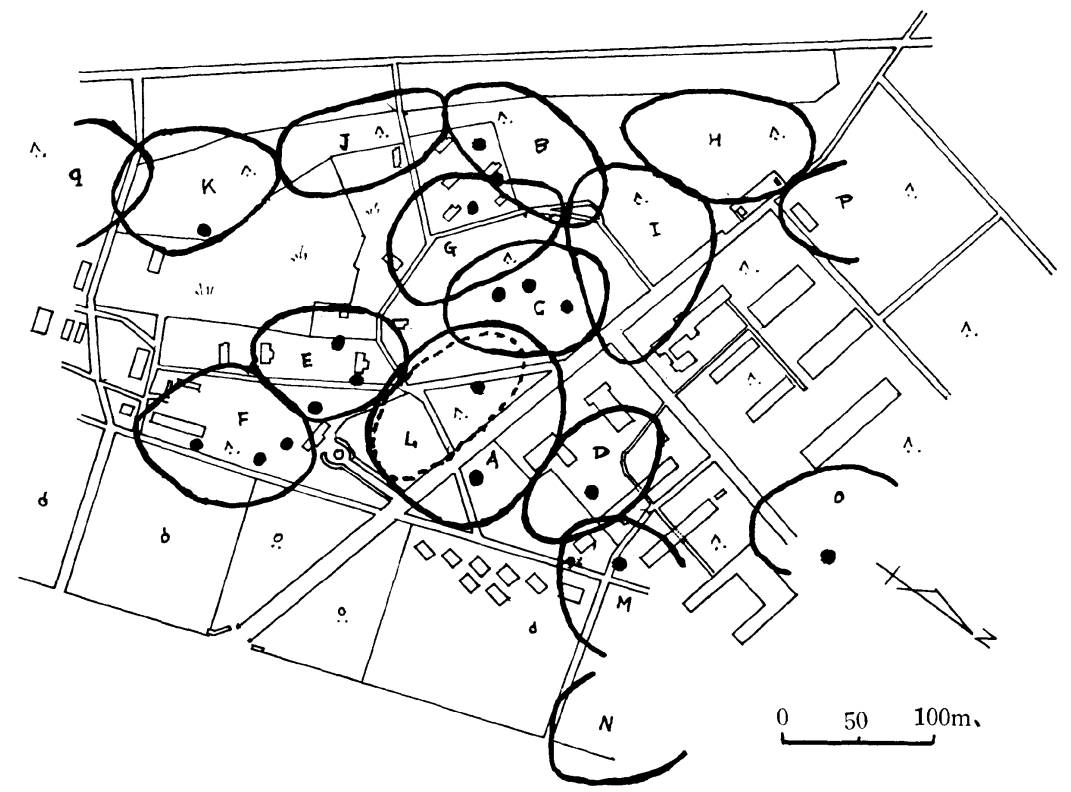

$\mathrm{ABC} \cdots \cdots+$ ナワバリの記号

ヒーつ後から侵入した単独雄のナワバリ

—大体のナワバリ

巣の位置

第11図 ナワバリの分布 (1996年度)

(104) 
った。従って雌は巣造り, 抱卵, 抱雛にたずさわるが,一方雄はこの間ナワバリ防衛に多くを 費している。

10. ナワバリ

\section{(1) ナワバリの分布}

クロッグミのナワバリは，営巣，巣材採取，採食等一連の行動を囀り範囲内で行なっている ことから，囀り範囲をナワバリとみなすことができよう。

第11図に信州大学農学部構内の一部に抢けるクロッグミのナワバリ分布を示した。分布地域 はいずれるアカマツ，ヒノキ林を含み，校舎，空地，道路等り含む比較的開けた場所である。

クロッグミはきわめて定住性の強い鳥で，繁殖期の初期に形成されたナワバリは任とんど移 動することなく最後まで保持される。また第11図に示すようにクロッグミのナワバリはきわめ て密にかたまった分布を示し，黒田（1969）的指摘しているように，良い環境でり孤立したナ ワバリをつくらず，ある地域に集まるといういわゆるナワバリコロニ一の社会性がみら机る。

ナワバリ面積は平均 $7300 \mathrm{~m}^{2}$ で blackbird の0.4〜0.6エーカー（Snow 1956）に比ぐると かなり大きいが，生息密度は blackbird の約 5.5 エーカー内に抢ける11〜17番いに比べこク ロッグミでは約 13ha 内に11番いとかなく低く， blackbird はクロッグミより一層コロニーに 近いナワバリを形成していることがわかる。従ってこのちがいは後に述べるようにナワバリの 型のちがいとしてわ現われている。

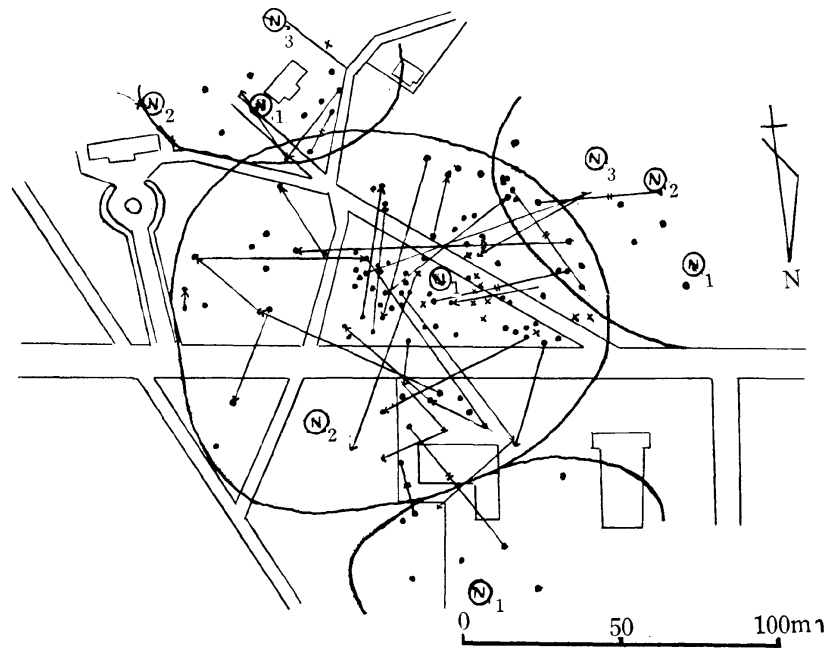

囀り地点 $X$ 争h地点 (0) 巣の位置

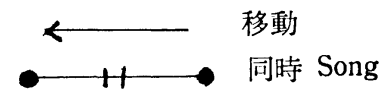

第12図 ナワバリの概要（A番は1 st brood の産卵・抱卵期）

(2) ナワバリ防衛

ナワバリの防衛には雌雄がた ずさわった。

争いは雄対雄, 雌刘雌, 雄対 雌の型が観察されたが，このう ち雄対雄による争いが最品多 い。第13図に1968年捻よび1969 年のひと番いに抦いて観察され た争い回数の各々16回，35回に おけるナワバリ防衛型の割合を 示したが，同種すなわちクロツ グミへの攻撃をしたるのは1968 年の観察では, 81.0\%, 1969年は $71.4 \%$ また異種への攻撃とし てアカモズ Lanius cristatus superciliosus に対してのみにみ られたが，それぞれ $19.9 \%$, $28.6 \%$ て同種間での争いが最子 多かった。また雌雄別の争い参加の割合では，雄の攻撃が多く，1968年の観察では雄による攻 撃が81.0\%，雌の攻撃が $13.0 \%$ ，雌雄での攻撃が $6.0 \%, 1969$ 年の各々は 80.0\%，11.4\%， $8.6 \%$ であった。 

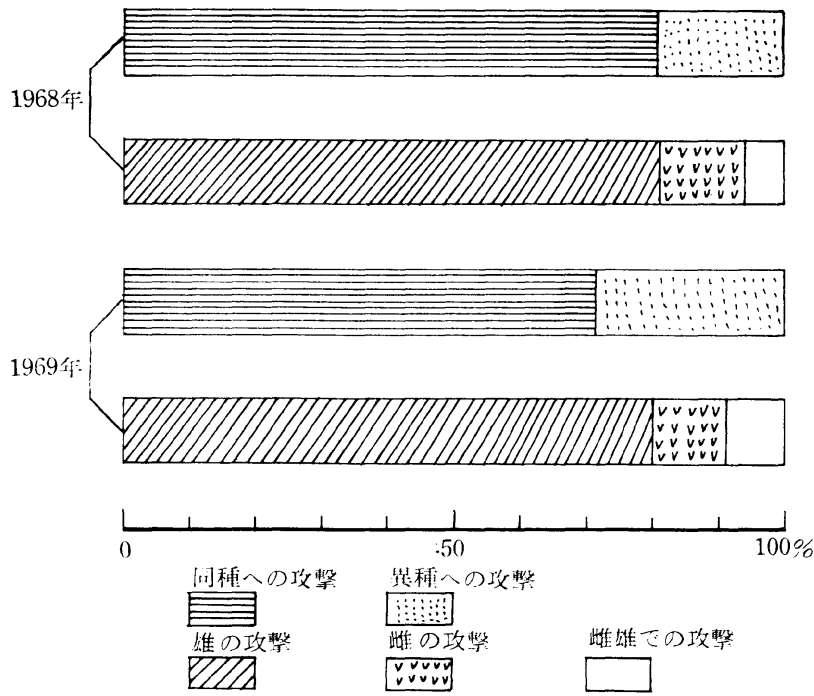

第13図 ナワバリ防衛型の割合
従ってナワバリ防衛には主と して雄がたずさわっているが， 争い形態は種によって異なる。 すなわち同種に対しては互にふ つかり合って激しい攻撃を行な い，時には長時間におよふ場合 がみられた。しかし，アカモズ に対してはきわめて突発的に警 戒声をともなって攻撃するが， 逆にアカモズから攻撃を受ける 場合りしばしばみられた。この ほか異種への攻撃はE番いの雄 によってヒヨドリ Hypsipetes amaurotis とキジバト Streptopelia orientalisに対してなさ れたのをみている。 Snow（19

56) が blackbirdについて述べているように，小さな鳥には比較的無関心で，スズメ Passer montanus, シジュラカラ Parus major, エナガ Aegithalos caudatus, コサメビタキMuscicapa latirostris, ウグイス Cettia diphone, センダイムシクイ Phylloscopus occipitalis 等: が巣より I〜2mに近づいても，全く攻撃をくわえなかった。クロツグミにおける攻撃はヒヨ ドリやキジハトトのような, 比較的大型の鳥に対してみられたように，害敵意識から攻撃をくわ えるるのむあるが，環境選択における生態的地位の同等な同種に対しては強い攻撃を行なって いる。またアカモズに対しても害敵意識からの攻撃が多分に含まれているようである。このほ かカケス Garrulus glandarius やハシボソガラス Corvus corone が林内を通過した場合激し い警戒声を発している。

ナワバリ行動には争いの他に囀りも含まれるが，育雛期に入ると囀り量はきわめて少なくな り，囀り範囲は巣の周辺だけに集中し，産卵，抱卵期の1/6に減少している。これは雛への給慨 のために巣への執着が堌大したことにもよるが，育㱀期における給慨の半分以上を雄が受け持 つことから当然ナワバリ防衛行動の減少として考えられる。Snow (1956) もナワバリ行動は 巣造りが始まる頃に最高潮に達するが，乙れ以後は次第に弱まり育雊期には最も低下すること を指摘している。第12図に示すように争い地点は巣近辺に集中して抢り，特にナワバリ防衛の 中核をなす場所が存在することがうかがえる。

(3) ワナバリの機能

クロッグミは前述したように巣材採取抢よび採食, 雛への給慨のための採飭, 㸚ぐら取り等 繁殖期に扣けるほとんどの活動をナワバリ内で行なっている。Mayr (1945, 伊藤 1967の引用 より）のナワバリの型の分類に従うと，クロッグミのナワバリはA型に属する。一方 Snow (1956) は blackbirdについて, 採食の一部はナワバリ内でも行なうが, 多くは花壇や芝生 のような共通の場所で採食することを述べいわゆる A 型と B 型の中間型に位置することを 示している。ナワバリの機能について蠟山（1961）は(1)番いの形成と維持，(2)個体群の自己調 
整，(3)雛のための食物の確保をその 3 大機能としている。またSnow は blackbrid に抢ける ナワバリの機能として，(1)巣の間隔あけ，(2)配嵎者の保護をあげ，(1)については，害敵からの 侵略に対して有利であり，(2)については番い維持のための機能を有するとしている。

クロッグミは番い間のほか他の個体に対してりはっきり識別をして抢り，巣の近くに侵入し た他の雄個体に対して, 雌り強い攻撃を行なっている。従ってナワバリが番いの維持に貢献し ていることは明らかである。また本調查地にはアカモズの個体数る多いことから，互に攻撃を くわえながらり重複ナワバリを形成するりのが多く，1968年の調査では両者の巣の間がわずか $3 \mathrm{~m}$ という近距離で繁殖している例が見出された。従ってクロッグミのナワバリは主として, 同種に対して防衛される地域であり，本種の持つナワバリが同種個体群の密度をコントロール する要因上してり考えられる。またナワバリ行動の一つである輔りとナワバリの関係について Davies \& Snow (1965) は song thrush における非繁殖期のナワバリと囀りの多さは食物 の量によいて変化することを見出して扒り, 食物条件に関連したナワバリの機能に関しては,

第 6 表 繁 殖 率

\begin{tabular}{|c|c|c|c|c|}
\hline 作 & 栄 & 産卵数 & 睬化数 & 栄立ち数 \\
\hline \multirow{7}{*}{1968} & A & 3 & 3 & 3 \\
\hline & $\mathrm{B}_{2}$ & 4 & 4 & 4 \\
\hline & $\mathrm{C}$ & 4 & 3 & 3 \\
\hline & $\mathrm{D}$ & 3 & 0 & 0 \\
\hline & $\mathrm{E}$ & 5 & 0 & 0 \\
\hline & $\mathrm{F}$ & 4 & 0 & 0 \\
\hline & G & $?$ & $?$ & 3 \\
\hline \multirow{17}{*}{1969} & $\mathrm{~A}_{1}$ & 4 & 4 & 3 \\
\hline & $\mathrm{A}_{2}$ & 5 & 4 & 2 \\
\hline & $\mathrm{B}_{1}$ & 4 & 0 & 0 \\
\hline & $B_{2}$ & 4 & 4 & 2 \\
\hline & $\mathrm{C}_{1}$ & 4 & 0 & 0 \\
\hline & $\mathrm{C}_{2}$ & 4 & 3 & 3 \\
\hline & $\mathrm{C}_{3}$ & 4 & 4 & 3 \\
\hline & $\mathrm{D}$ & 4 & 0 & 0 \\
\hline & $\mathrm{E}_{1}$ & $?$ & $?$ & 0 \\
\hline & $\mathrm{E}_{2}$ & $?$ & $?$ & 3 \\
\hline & $\mathrm{E}_{3}$ & 4 & 4 & 4 \\
\hline & $\mathrm{F}_{1}$ & $?$ & $?$ & 3 \\
\hline & $F_{2}$ & 4 & 4 & 4 \\
\hline & $\mathrm{F}_{3}$ & 3 & 2 & 2 \\
\hline & G & 4 & 4 & 4 \\
\hline & $\mathrm{O}$ & 3 & 3 & 0 \\
\hline & $\mathrm{R}$ & 4 & 4 & 0 \\
\hline 平 & 匀 & 3.9 & 2.5 & 1.9 \\
\hline
\end{tabular}

$\mathrm{A}_{1}, \mathrm{~A}_{2} \cdots \mathrm{B}_{1}, \mathrm{~B}_{2} \cdots$ 等は同一番的一繁殖期に打ける繁 殖順を示す。
さらに考察を進める必要があろう。

11. 繁殖摔

第 6 表に1968年および1969年に観察 された24巣についてその繁殖状況を示 した。

産卵数は $3 \sim 5$ 卵で平均 3.9 卵であ った。また平均卵孚化数は 2.5 羽, 平均 巣立ち数は 1.9 羽, 平均孵化率は64.1 \%，産卵数に対する巣立ち率は48.7\% 孵化数に対する巣立ち率は76,0\%であ った。クロッグミの巣は抱卵, 育雛期 に害敵に犯されるるのがきわめて多く 全巣のうち $37.5 \%$ が何らかによって害 され，卵あるいは勸が消失している。 従って, 卵消失巣 $(\mathrm{C} \cdot \mathrm{E} \cdot \mathrm{F}-1968$, $\mathrm{B}_{1} \cdot \mathrm{C}_{1} \cdot \mathrm{D}$-1969） あるいは雛消失巣 を除いた場合平均卵孚化数は 3,5 羽，平 均卵孚化率は89,7\%, 平均巣立ち数は3.1 羽, 産卵数に対する平均巣立ち率も $79.5 \%$ と高くなり，繁殖率の低下は害 敵によってもたらされる卵媰の消失が 最大の原因となっている。これらの消 失巣についてみると巣中に全く残骸が 見出されないことからほとんどはへビ によって，のみ込まれたことが考えら れる。1 繁殖期におけるひと番い当り の生産炛数は, 繁殖回数の調查対象と 
した1969年の $\mathrm{A} \sim \mathrm{G}$ 番いについてみると，平均 4.7 羽で blackbird の 4.1 羽 (Snow 1958) とほぼ近い値を示している。

\section{IV 摘 要}

1. 長野県伊那市郊外の信州大学農学部棈内で1968年打よび1969年の两年にわたって,クロッグミTurdus cardis cardis の繁殖生活を調查した。

2.クロッグミは 4 月中旬に渡来を開始し，1月下旬から繁殖を開始した。繁殖期の番い当り繁殖回数は 平均 2.1 回（巣立ち失敗巣を含む）で，巣立ちから次の産卵に入るまで 5.6 日を要した。

3. クロッグミの 1 回の繁殖を巣造り期，産畉期，抱卵期，抱雛期，家族期の 5 期に区分した。

4. 巣造りは雌のみによって行なわれ，巣材採取は全てナワバリ内であった。

5. 産卵は 1 日 1 卵づつなされ，産卵時刻は $8: 00 〜 12: 00$ 間でらずれも午前中であった。

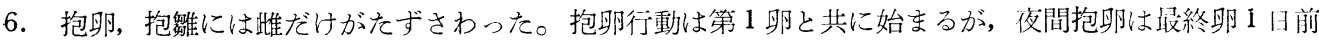
から行索われ，終卵日から完全抱莭に入った。

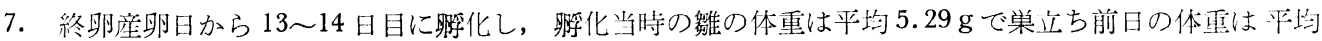
$45.54 \mathrm{~g}$ であった。

8. 抱雛行動は雛の成長と共に次第に減少したが，夜間抱雛は最後まで行なわれた。

9. 給䬣は雌雄によって睬化日から行なわれ，1日の給慨回数は70〜158回であった。

10. 雛は睬化後11〜13日目に巣立ち，その後約 20 日間家族群が構成されたが，雌は次の繁殖に入っ立埸 合雛への給䬣を約 1 週間続けただけであった。

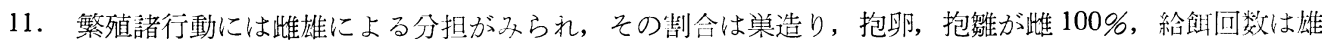
$61.6 \%$, 雌38.4\%, ナワパリ争いは雄が $81.6 \%$, 雌が18.4\%であった。

12. ナワバリは平均 $7300 \mathrm{~m}^{2}$ の面積を持ち，Mayr（1935）のナワバリ分類によると A 型に衙する。ナワ バリ防衛には主として雄がたずさわり，同種に対する攻撃が最も多かった。

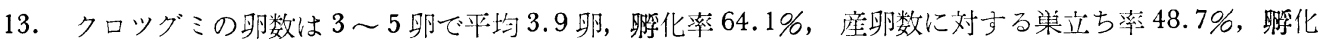
数に対する栄立ち率は $76.0 \%$ で，1繁殖期の番い当り平均生崖雏数は 4.7 羽であった。

14. 天敵としてへビが考えられる。

\section{引用文 献}

Davies, P. W. \& Sncw, D. W. 1965. Territory and food of the Song Thrush. Brit. Birds 5 (1): $161 \sim 175$.

羽田健三・小潚順子 1968. ヒバリの生活史に関する研究 1 . 繁殖生活 山階鳥研究報 5 (1) : 72 84.

羽田健三・高橋庸子 1968. アカモズの生活史に関する研究 1. 繁殖期 日生態会誌 18 (2) : 47〜 56.

羽田健三・寺西けさん 1968. オオヨジキリの生活史に関する研究 1. 繁殖生活 日生態会誌 18 (3) $: 100 \sim 109$.

羽田健三・渡辺 博 1969. アカ八ラの繁殖生活に関する研究 志賀自然教育研究施設研究業績 $8: 69$ $\sim 77$.

伊藤嘉昭 1967. 比較生態学 岩波書店

黒田長久 1966. クロツグミのなわばり観察 山階鳥研報 4 (6) (no. 26) : 469〜480.

黑田長久 1969 . 鳥類の研究 (生態) 新思潮社

蠟山朋雄 1961. ジジュウカラの生活 自然 $16: 66 〜 75$.

Snow D.W. 1956. Territory in the Blackbird Turdus merula. Ibis $98: 438 \sim 447$. 
Snow D.W. 1958. The breeding of the Blackbird Turdus merula at Oxford. Ibis $100: 1 \sim 29$. 浦本昌紀 1966. 鳥類の生活 紀伊国屋書店

\section{Life history of the Grey Thrush Turdus cardis \\ Breeding ecology \\ Kazuto Miyazawa}

1. This report describes the breeding observations of the Grey Thrush Turdus cardis, made in 1968 and 1969 in the campus of Shinshu University in Nagano, 780m above sea level.

2. It arrives here in late April. A pair raised average 2.1 brood per season including unsuccessful cases. The interval from the first brood flying to the laying of the first egg of second brood was average 5.6 days.

3. The female only worked for nest-building and the nest material were collected within the territory.

4. Normally eggs were laid daily between 8 and 12 a. m.

5. The female only incubated and brooded. The incubation was gradually commenced before the clutch is completed and night incubation was started on the day before the laying of the last egg. The incubation period was $12 \sim 13$ days.

6. The female's brooding decreased as the chicks grew, but her night brooding was continued all through the nestling period. The chicks grew from $5.29 \mathrm{gr}$. to $45.54 \mathrm{gr}$. while their nestling life.

7. Both sexes fed the chicks from the day of hatching and the feeding frequency ranged from 70 to 158 times a day.

8. The nestling period was $11 \sim 13$ days (counting from the hatching of the first chick). The post-fledging family life lasted 20 days and when the female began her second nest-building, she usually fed the young only for about a week.

9. The female shared $100 \%$ nest-building, incubation and brooding, $38.4 \%$ feeding (male $61.6 \%$ ) and the male engaged $81.6 \%$ in territory defense (the female $18.4 \%$ ).

10. The territory was Type A of Mayr (1935) and was average $7,300 \mathrm{~m}^{2}$ in size. It was defended principally against the same species but was also aggressive to some other larger species.

11. The clutch ranged $3 \sim 5$ eggs with the mean 3.9 and the hatching rate was $64.1 \%$, the fledging rate being $48.7 \%$ from the egg and $76.0 \%$ from number hatched.

In 24 nest examined the average 4.7 young was produced per pair per season.

12. Snakes may be one of the important predator in this species.

1., 322, Awasa, Koshoku City, Nagano, 387 